\title{
Availability and Accessibility of Physical Facilities Provision that Support PWDs
}

\author{
Ng Wee Fern, Rozilah Kasim, Mohd Idrus Mohd Masirin
}

\begin{abstract}
This document describes well the data analysis and document review results in order to guarantee that the structures comply with the building regulations. In addition, measurement and photography observations were done to determine the availability and accessibility of people with disabilities (PWDs) using facilities in Universiti Tun Hussein Onn Malaysia (UTHM). Besides introducing the process and function of the study, it also stating clearly the first research objective to be analysing. Furthermore, this paper presents the research framework highlight on research objective 1 that is to determine the physical facilities provision that support availability and accessibility for PWDs at UTHM.
\end{abstract}

Keywords: availability, accessibility, PWDs

\section{INTRODUCTION}

The method or instruments used in this study are the byproducts of quantitative and qualitative research. Cresswell and Clark (2011) describe this method as a design, which involves at least one quantitative method (design to collect numbers) and one qualitative method (design to collect words). The research used qualitative method with observation, measurement, photography and document review are which is qualitative in nature used in this result to find out the availability and accessibility physical facilities for PWDs, explore with the enacted regulation and existing standards. A positive safety culture cannot be bought; it is not a manual, a program, a video or a canned presentation (Simon \& Frazee, 2005). Observation via checklist, measurement with charted architect, photography on physical facilities for PWDs toward ninety-nine (99) buildings has been conducted along the research period. There are number of facilities PWDs provided in UTHM but inaccessible and mostly the specifications are not according to enacted regulation and standard such as Malaysia Standard and Universal Design.

\section{METHODOLOGY}

There are two primary types of research design, namely qualitative and quantitative. However, according to Yin (2011), qualitative method can be used to complete a research based on the nature of research.
The research used qualitative method with observation, measurement, photography and document review are which is qualitative in nature used in this result to find out the availability and accessibility physical facilities for PWDs, explore with the enacted regulation and existing standards. Figure 1 illustrate the qualitative data collection in this research.

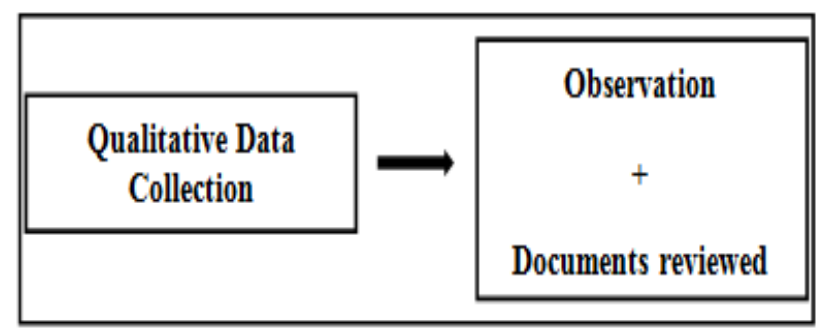

Fig. 1 Qualitative Data Collection Structure to evaluate the facilities provisions for PWDs at UTHM

There are two types of observations namely participating observation and non-participating observation, for which the latter type is commonly applied in qualitative research. For non-participant observations, the observer is not directly involved in any observed situation. In this study, observation via checklist, measurement with charted architect, photography on physical facilities for PWDs toward ninety-nine (99) buildings has been conducted along the research period. Attachment charted architect in three (3) months shown in Table 1. The details of checklist observation such as Table 2 .

Table. 1 Details of observation (Field study, 2017)

\begin{tabular}{|c|l|l|}
\hline No. & \multicolumn{1}{|c|}{ Particular } & \multicolumn{1}{c|}{ Details } \\
\hline 1. & $\begin{array}{l}\text { Date of } \\
\text { observation }\end{array}$ & $\begin{array}{l}\text { a. May and September } \\
\text { of 2017, } \\
\text { b. June of 2017 } \\
\text { c. July of 2017 }\end{array}$ \\
\hline 2. & $\begin{array}{l}\text { Duration of } \\
\text { observation }\end{array}$ & $\begin{array}{l}\text { Each observation taking } \\
\text { three hours to complete }\end{array}$ \\
\hline
\end{tabular}

Revised Manuscript Received on June 22, 2019.

Ng Wee Fern, Universiti Tun Hussein Onn Malaysia, 68400 Parit Raja, Batu Pahat, Johor.

Rozilah Kasim, Universiti Tun Hussein Onn Malaysia, 68400 Parit Raja, Batu Pahat, Johor.

Mohd Idrus Mohd Masirin, Universiti Tun Hussein Onn Malaysia, 68400 Parit Raja, Batu Pahat, Johor. 
Table. 2 Results for disabled facilities at main building and infrastructure

\begin{tabular}{|c|c|c|}
\hline NO & Description & Yes / No \\
\hline 1. & $\begin{array}{ll}\text { Car park } \\
\end{array}$ & \\
\hline A. & Is the surface levelled with anti-resistance? & No \\
\hline B. & Are the car park lots painted with contrast colours or sign to differentiate with others? & Yes \\
\hline C. & Is there provided sufficient area for accessibility? & No \\
\hline D. & Are the pedestrian lanes provided? & No \\
\hline E. & Are the car park lots located at accessible area? & Yes \\
\hline F. & Is the car park lots located at well ventilated and clear light area? & No \\
\hline G. & Is the picking up and dropping off area provided? & No \\
\hline 2. & Pathways & \\
\hline A. & Is there sufficient space for wheelchair users to manoeuvre? & No \\
\hline B. & Are the pathways well connected? & No \\
\hline 3. & Ramp and kerb ramp & \\
\hline A. & Is the surface levelled with anti- slip? & No \\
\hline B. & Is the ramp width enabling for wheelchair users to access? & No \\
\hline C. & Is the gradient of ramp proper provided? & Too steep \\
\hline D. & Are the handrails provided? & Yes \\
\hline 4. & Guiding block & \\
\hline A. & Are the guiding blocks provided? & Yes \\
\hline B. & Are the guiding blocks placed at proper places? & Yes \\
\hline 5. & Handrail & \\
\hline A. & Is the handrail presented in firm and comfortable grip texture? & No \\
\hline B. & Is the plate Braille available at beginning and end of handrail? & No \\
\hline C. & Is the handrail painted with contrast colours with surrounding area? & No \\
\hline D. & Is the handrail provided at proper height? & No \\
\hline 6. & $\begin{array}{ll}\text { Staircase } \\
\end{array}$ & \\
\hline A. & Is the staircase painted with sharp colours? & No \\
\hline B. & Are the nosing illuminated or protruded? & No \\
\hline C. & Are the handrails provided? & Yes \\
\hline 7. & $\begin{array}{ll}\text { Lift } \\
\end{array}$ & Yes / No \\
\hline A. & Is there sufficient space for wheelchair users to manoeuvre? & Yes \\
\hline B. & Is the lift located at accessible places? & Yes \\
\hline C. & Is the doorway width enabling for wheelchair users to access? & Yes \\
\hline D. & Is the lift door indicated in bright colours with surrounding wall? & Yes \\
\hline E. & Are the Braille types label buttons presented? & Yes \\
\hline F. & Is the lower internal operating panel presented? & Yes \\
\hline G. & Is the handrail installed? & No \\
\hline H. & Are the visual and voice indicators installed? & No \\
\hline I. & Is the lift floor covered with non-slip material? & No \\
\hline 8. & Doorways & \\
\hline A. & Is the doorway width enabling for wheelchair users to access? & Yes \\
\hline B. & Is the threshold levelled with kerb ramp? & No \\
\hline C. & Is the mechanism door provided at entrance? & No \\
\hline 9. & $\begin{array}{ll}\text { Signage } \\
\end{array}$ & \\
\hline A. & Are the directions clear indicated? & Yes \\
\hline B. & Are the signage lit at night? & Yes \\
\hline C. & Are the signage used contrast colours to differentiate the figure from background? & Yes \\
\hline D. & Are the signage placed at proper places? & Yes \\
\hline 10. & Toilet & \\
\hline A. & Is the doorway width enabling for wheelchair users to access? & Yes \\
\hline B. & Is there sufficient space for wheelchair users to manoeuvre? & \\
\hline
\end{tabular}




\begin{tabular}{|c|l|c|}
\hline C. & Are the handrails provided? & No \\
\hline D. & Are the emergency fittings provided? & No \\
\hline
\end{tabular}

Analysis on Specifications of PWDs facilities provision at UTHM

\section{Threshold ramps}

Lecture Hall A, ramp length is $1400 \mathrm{~mm}$ and landing surface is $3900 \mathrm{~mm}$ Lecture Hall, the ramp length is 5300 $\mathrm{mm}$ and landing surface is $4700 \mathrm{~mm}$ All ramps in UTHM. It is too long and will cause wheelchair users to collapse.

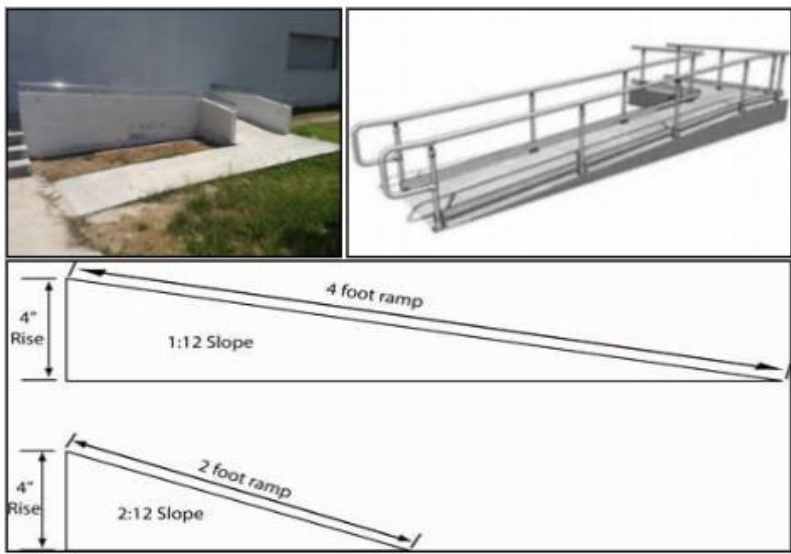

Fig. 2 Steep and Gradient Ramp

\section{Accessible Entrances}

Inaccessible for entrance door, toilet door and lecture hall. Entrance doors are not easily open as it requires more force to open. Experiment had been done by using ergonomic test kit; the door had to push by using $90 \mathrm{~N}$ to $100 \mathrm{~N}$. At the leading edge, the highest strength for an individual to manually handle a self-sealing door cannot be larger than 20 N. However, this condition disputes to the fire safety standard BS EN 1154 Table 1. This means that door sealers of size three -EN 3- \& above should be used on fire doors, needing a closing power of $20 \mathrm{~N}$, equal to an opening power of $36.35 \mathrm{~N}$ (Figure 3).

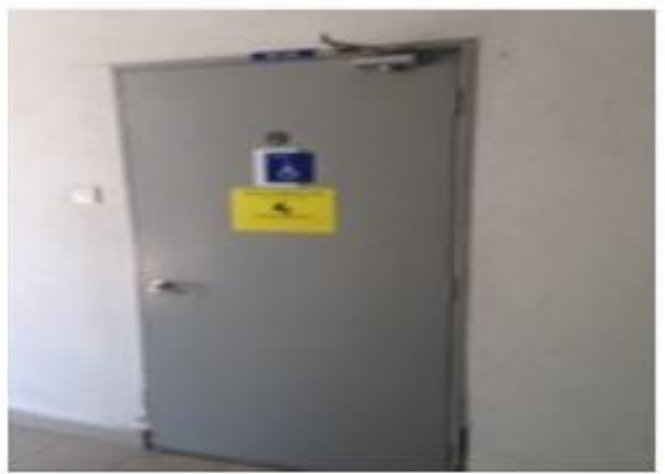

Fig. 3 Door \& Entrance

\section{Passing and Turning spaces}

The corridor at the entrance is also narrow and angular. It will cause them an inconvenience every time they enter and exit the lecture hall and Administration buildings $(125 \mathrm{~cm} \times 150 \mathrm{~cm})$ shown as Figure 4.

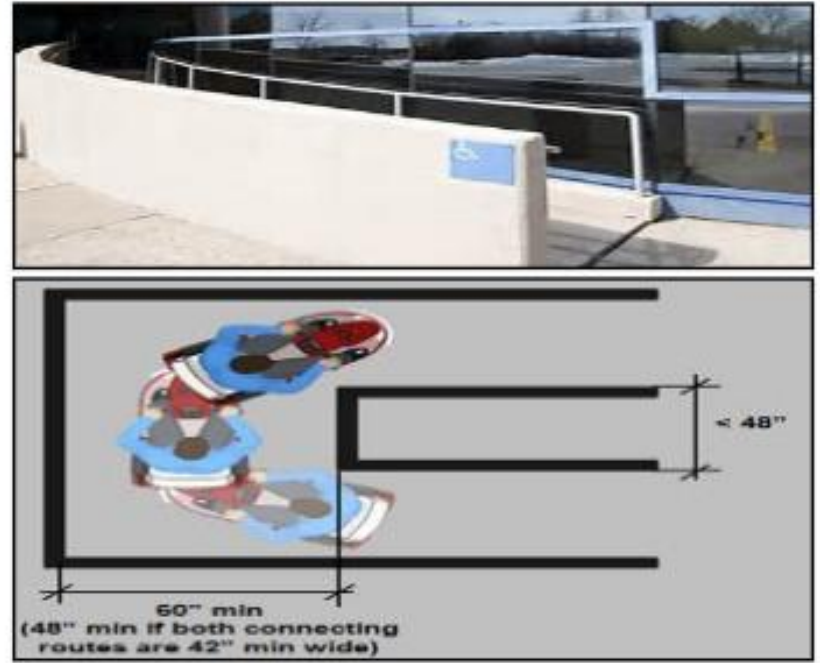

Fig. 4 Passing and Turning Space

\section{Car parking}

The measurement parking lot in UTHM fulfilled the standard but there were no kerb ramp install outside access aisle.
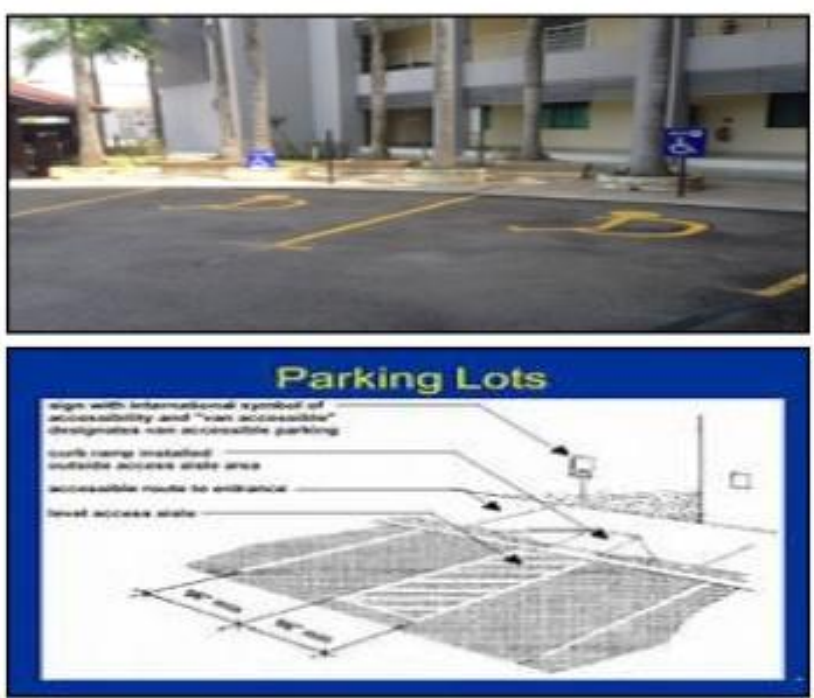

Fig. 5 Side dox Flooring 


\section{Wheelchair seating spaces in auditorium}

As referred to in the Malaysian Standard, wheelchair user spaces should be given in ratio 1 space to each 200 seats, or publicly available, with a minimum of 2 spaces for wheelchair users. However, there are no lecture hall in UTHM were provided with the special space for wheelchair user. As Figure 6, there is just a small space at front of the lecture hall, near to lecturer table which possible for wheelchair students to access the lecture.
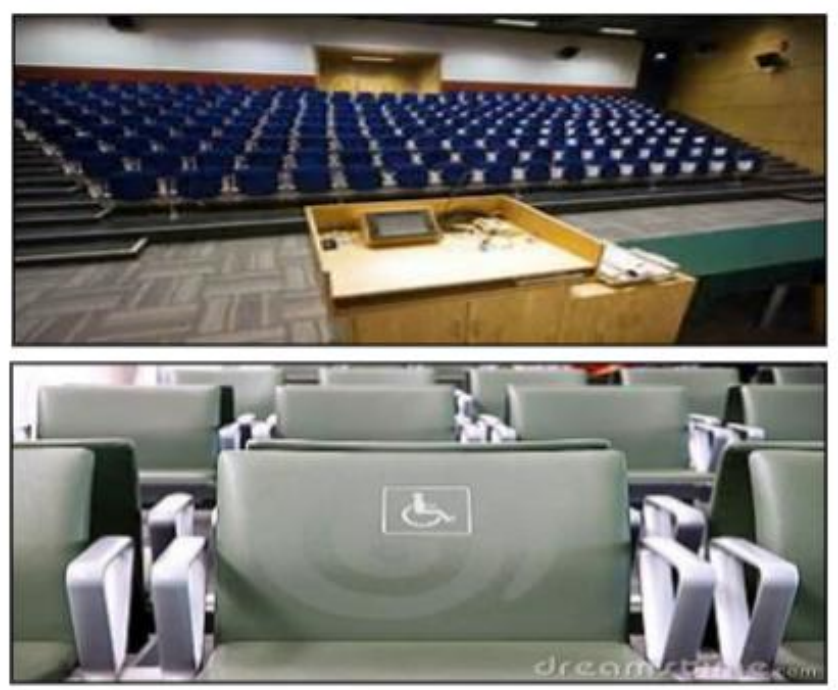

Fig. 6 Wheelchair seating spaces in auditorium

Lifts

Significant additional prescription has been included on the uses (and usage limitations) of various lifting devices. To detect passengers and control the gate, a photo-electric sensor must be installed. (Figure 7)

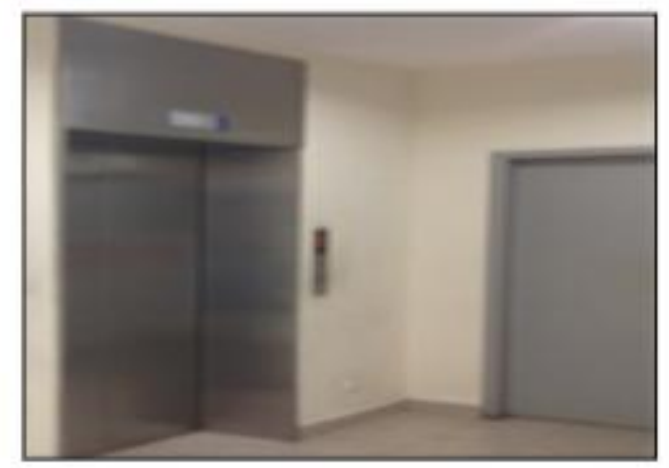

Fig. 7 Photo- electric sensor

\section{Sanitary}

The measurement of water closets from Block E and near Lecture Hall A were taken. As referring to Malaysian Standard, the water closets, handrail and grab bar are not fulfilling the MS. Figure 8 were shown the different between the measurements. Figure 8 shown different between the standard and provided by UTHM.

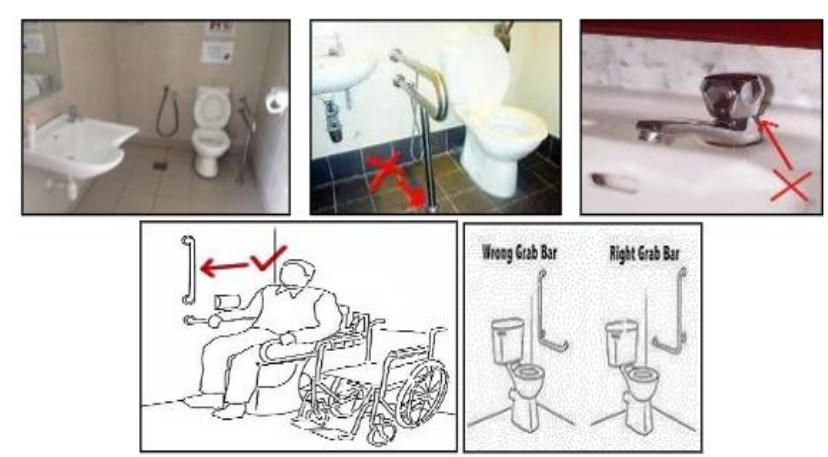

Fig. 8 Water Set

\section{Accessible links between buildings.}

From the observation, links between buildings are in good condition. There is roofed pathway between block B, cafeteria and Block $\mathrm{E}$ that fulfill the standard as shown in Figure 9, but the floor is not really suitable especially rainy day.

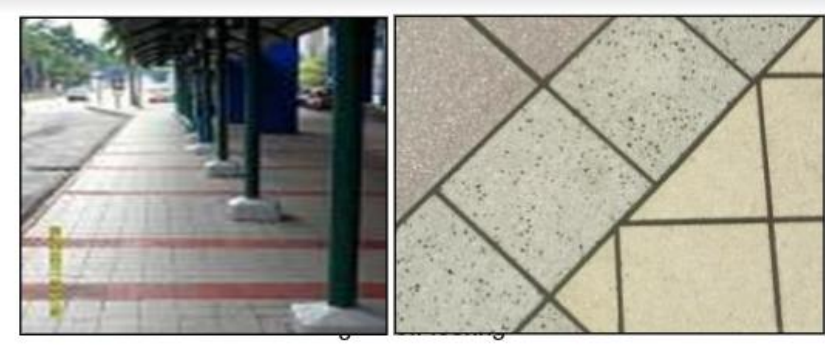

Fig. 9 Flooring

\section{RESULTS AND DISCUSSION}

The findings shown the implementation enacted legislation toward the availability facilities PWDs in UTHM is not fully implied and it also shown sixty-two (62) buildings totally without any physical facilities provided, only nine (9) buildings complete with physical facilities PWDs, five (5) buildings with 3 point scored and fifteen (15) buildings with 1-point score. There are four (4) indicators of physical facilities PWDs, Toilet, Parking, Ramp and lift (another 5 indicators never provided in UTHM) which carry 1 point each. The full point is 4 . For the observation and checklist investigation resulted only $9.09 \%$ buildings UTHM fully provided the facilities, $21.21 \%$ partly provided facilities PWDs and 62.63 totally did not provided physical facilities to PWDs in UTHM.

\section{CONCLUSIONS}

Upon basis of all analytical results and extensive discussion conclude that all research questions and objectives achieved in this chapter. For first research question and objective: To determine the physical facilities provision in UTHM focusing on availability, accessibility, specification identified existing facilities and layout of person with disabilities in UTHM were categorised into overall nine (9) specification physical facilities according to

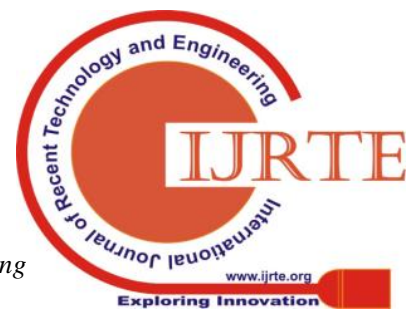


Malaysia Standard and Universal Design, namely as:

i) Threshold ramps

ii) Accessible Entries

iii) Passing and Turning spaces

iv) Car parking

v) Wheelchair seating spaces in lecture hall

vi) Glazing Special safety arrangements

vii) Lifts Significant added prescription on the uses (and limits to use of) various lifting devices has been included.

viii) Sanitary facilities for people with ambulant disabilities for each sex are proposed to be necessary at each toilets bank where two or more toilets are provided. Including grab bar, suits, alert bell etc.

ix) Accessible links between buildings.

This answered the first research question and objective: Do the provisions of physical facilities in UTHM support PWDs? To determine the physical facilities provision that supports availability and accessibility for PWDs in the area of case research. At the end of the chapter, the first objective was satisfied, along with finding answers for the first research question as well.

\section{REFERENCES}

1. Creswell, J.W. \& Clark, V. L. (2011). Designing and Conducting Mixed Method Research. 2nd Edition. United State of America: Sage.

2. Simon, S. I., \& Frazee, P. R. (2005). Leadership-driven culture change at General Motors (pp. 36-44, Publication). Retrieved May 13, 2018, from http://www.culturechange.com/wpcontent/uploads/2014/11/GMJan2005.pdfYin, R. K. (2011). Case Study Research Design and Methods. 4th Ed. United States, America: SAGE

3. Yin, R. K. (2011). Qualitative Research from Start to Finish, First Edition. New York, USA: Guilford Press.

4. Abdullah, N., Hanafi, H., \& Hamdi, N. I. M. (2017). The Rights of Persons With Disabilities in Malaysia: The Underlying Reasons for Ineffectiveness of Persons with Disabilities Act 2008. International Journal for Studies on Children, Women, Elderly And Disabled, Vol. 1 (January).

5. Asiah Abdul Rahim, Samad, N. A. A., \& Rahim, C. R. C. (2015). Overview of Universal Design Application and Accessibility in Major Cities of ASEAN Countries. . Paper presented at the 2nd International Conference on ASEAN Community 2015, Kuala Lumpur.

6. Asiah Abdul Rahim, Zen, I., Samad, N. A. A., Rahim, C. R. C., \& Badhrulhisham, A. (2014, 11th - 13th November 2014). Investigation on the Accessibility in Transportation Hubs: Upgrades in London. Paper presented at the 5th International Conference for Universal Design in Fukushima \& Tokyo 2014 Tokyo.

7. Bendixen, K. (2010, 2nd November 2014). Perspective from Denmark: Design for All - Point of no Return! Paper presented at the 3rd International Conference for Universal Design in Hamamatsu, Japan 2010, Hamamatsu.

8. Bickenbach, J. E., Chatterji, S., Badley, E. M., \& Üstün, T. B. (1999). Models of disablement, universalism and the international classification of impairments, disabilities and handicaps.

9. Social Science \& Medicine, 48(9), 1173-1187. doi:http://dx.doi.org/10.1016/S02779536(98)00441-9

10. The Center for Universal Design (CUD), NCSU. (2008). Retrieved from https://www.ncsu.edu/ncsu/design/cud/about_ud/udhistory.htm

11. Creswell, J. W. (2009). Research Design: Qualitative, Quantitative and Mixed Methods Approaches (3rd Edition ed.). USA: SAGE Publications.

12. The EIDD Stockholm Declaration. (2004).

13. Erkilic, M. (2011). CONCEPTUAL CHALLENGES BETWEEN UNIVERSAL DESIGN AND DISABILITY IN RELATION TO THE BODY, IMPAIRMENT, AND THE ENVIRONMENT: WHERE DOES THE ISSUE OF DISABILITY STAND IN THE PHILOSOPHY OF UD? Universal Design and Disability, 2(METU JFA ). doi:DOI: 10.4305/METU.JFA.2011.2.9
14. Evcil, A. N. (2012). Raising Awareness about Accessibility. Procedia Social and Behavioral Sciences, 47, 490-494. doi:http://dx.doi.org/10.1016/j.sbspro.2012.06.686

15. Fletcher, V. (2016). Inclusive/universal design: People at the center of the design process The Routledge Companion for Architecture Design and Practice: Established and Emerging Trends (pp. 251-268): Taylor and Francis.

16. Froyen, H. (2015). Universal Design for The Human-Made Environment We Share. Paper presented at the 4th International Conference on Universal Design in the Built Environment 2015 Sharing the World (ICUDBE2015), Perbadanan Putrajaya

17. Gray, J. A., Zimmerman, J. L., \& Rimmer, J. H. (2012). Built environment instruments for walkability, bikeability, and recreation: Disability and universal design relevant?

18. Disability and Health Journal, 5(2), 87-101. doi:http://dx.doi.org/10.1016/j.dhjo.2011.12.002

19. Groat, L., \& Wang, D. (2002). Architectural Research Methods. USA: John Wiley \& Sons.

20. Guimarães, M. P. (2016) Universal design criteriain standardsand codes about accessibility of built environmentsin Brazil. Vol. 229. 3rd International Conference on Universal Design, UD 2016 (pp. 121-130): IOS Press.

21. Harrison, J., \& Dalton, C. (2015). THE FAMILIAR AND THE STRANGE: THE LIMITS OF UNIVERSAL DESIGN IN THE EUROPEAN CONTEXT. JOURNAL OF

22. UNIVERSAL DESIGN IN THE BUILT ENVIRONMENT, 1(1), 4967.

23. Harrison, J. D. (2001). Housing for Older Persons in Southeast Asia: Evolving Policy and Design. In W. F. E. Preiser \& E. Ostroff (Eds.), Universal Design Handbook: McGrawHill Education.

24. Hussein, H., \& Yaacob, N. M. (2012). Development of Accessible Design in Malaysia. Procedia - Social and Behavioral Sciences, 68, 121-133. doi:http://dx.doi.org/10.1016/j.sbspro.2012.12.212

25. Imrie, R. (2000). Disabling environments and the geography of access policies and practices. Disability \& Society, 15(1), 5-24.

26. Imrie, R. (2012). Universalism, universal design and equitable access to the built environment. Disability and Rehabilitation, 34(10), 873882. doi:10.3109/09638288.2011.624250

27. Imrie, R., \& Kumar, M. (1998). Focusing on Disability and Access in the Built Environment. Disability \& Society, 13(3), 357-374. doi:10.1080/09687599826687

28. Iwarsson, S., \& StÅH1, A. (2003). Accessibility, usability and universal design-positioning and definition of concepts describing personenvironment relationships. Disability and Rehabilitation, 25(2), 57-66. doi:10.1080/dre.25.2.57.66

29. Kadir, S. A., \& Jamaludin, M. (2012). Applicability of Malaysian Standards and Universal

30. Design in Public Buildings in Putrajaya. Procedia - Social and Behavioral Sciences,

31. 36, 659-669. doi:http://dx.doi.org/10.1016/j.sbspro.2012.03.072

32. Kadir, S. A., \& Jamaludin, M. (2013). Universal Design as a Significant Component for Sustainable Life and Social Development. Procedia - Social and Behavioral Sciences, 85, 179-190. doi:http://dx.doi.org/10.1016/j.sbspro.2013.08.349

33. Kamarudin, H., Hashim, A. E., Mahmood, M., Ariff, N. R. M., \& Ismail, W. Z. W. (2012). The

34. Implementation of the Malaysian Standard Code of Practice on Access for Disabled Persons by Local Authority. Procedia - Social and Behavioral Sciences, $\quad 50, \quad 442-451$ doi:http://dx.doi.org/10.1016/j.sbspro.2012.08.048

35. Kanter, A. S. (2011). The Law: What's Disability Studies Got To Do With it or An Introduction to Disability Legal Studies. Columbia Human Rights Law Review, 42(2), 403.

36. Kanter, A. S. (2015). The development of disability rights under international law: from charity to human rights. Abingdon: Routledge. 